Arq. Bras. Med. Vet. Zootec., v.67, n.5, p.1327-1334, 2015

\title{
Energetic status of crossbreed dairy cows during transition period in two different seasons
}

\author{
[Perfil energético de vacas leiteiras mestiças no período de transição \\ em duas estações do ano] \\ T.F. Moreira, E.J. Facury Filho, R.M. Meneses, F.L.M. Mendonça, \\ J.A.M. Lima, A.U. Carvalho \\ Escola de Veterinária - EV-UFMG - Belo Horizonte, MG
}

\begin{abstract}
We used 31 crossbreed dairy cows to compare the energetic profile in summer and winter. Blood samples were taken weekly prepartum, at calving and on days 2, 5, 10,15, 21 and 30 postpartum. All metabolic indicators analyzed were influenced by the physiological status. The glucose concentrations were higher during winter while the triglyceride concentrations and lactate dehydrogenase (LDH) were higher in the summer. The season influenced the concentrations of cholesterol, AST and GGT, showing a different pattern between summer and winter. Non-esterified fatty acids (NEFA) and beta-hidroxibutirate (BHB) were not influenced by the season. Cows that calved during winter had a greater body condition score (BCS) and lost more BCS until calving. During summer, $32.26 \%$ of the animals and $29.03 \%$ during winter had NEFA concentrations above the optimum level and $22.58 \%$ of the animals in summer and $19.35 \%$ in the winter had subclinical ketosis at some point during the transition period, making then more susceptible to diseases.
\end{abstract}

Keywords: NEFA, monitoring, herd health, heat stress

\section{RESUMO}

Foram utilizadas 31 vacas leiteiras mestiças para comparar o perfil energético em duas estações, verão e inverno. Amostras de sangue foram colhidas semanalmente durante o pré-parto, no dia do parto e nos dias dois, cinco, 10, 15, 21 e 30 do pós-parto. Todos os metabólitos analisados foram influenciados pelo estádio fisiológico. As concentrações de glicose foram maiores no inverno, enquanto as concentrações de triglicérides e lactato desidrogenase (LDH) foram maiores no verão. As concentrações de colesterol, AST e GGT mostraram um padrão de comportamento diferente entre o verão e o inverno. Ácidos graxos não esterificados (NEFA) e beta-hidroxibutirato (BHB) não foram influenciados pela estação do ano. As vacas que pariram durante o inverno tinham um escore de condição corporal (ECC) maior e perderam mais ECC até o parto. No verão, 32,26\% e, no inverno, 29,03\% dos animais apresentaram concentrações de NEFA acima do recomendado no pré-parto; 22,58\% dos animais no verão e 19,35\% no inverno tiveram cetose subclínica em algum momento do período de transição, tornando-os mais suscetíveis a outras doenças.

Palavras-chave: AGNE, monitoramento, saúde do rebanho, estresse por calor

\section{INTRODUCTION}

During the transition period of dairy cows, which is between three weeks pre-partum and three weeks postpartum, the body undergoes various physiological adaptations, causing large changes in the metabolic profile. All these adaptations occur in a short period of time and contribute to most of the health problems of dairy cows, including metabolic and infectious diseases.
The analysis of blood metabolites permits the evaluation of the incidence of metabolic disease in its clinical and subclinical forms, aiding in monitoring the energy, protein and mineral metabolism (Leblanc et al., 2005; Mulligan et al., 2006). This is part of the medicine production philosophy, which is based on prevention and monitoring of herd health in order to reconcile health, animal welfare and productivity (Leblanc, 2010; Stengärde, 2010).

Recebido em 18 de março de 2015

Aceito em 11 de junho de 2015

E-mail: tiago_facury@yahoo.com.br 
The intensification of milk production systems brings new challenges to maintain the health of each individual and the herd and thus the use of the metabolic profile of animals during the transition period has great potential to improve management and nutrition, making clear the deficient aspects and enabling faster, objective and efficient action. There is much information about the metabolic profile of Holstein cows, but little regarding crossbreed, which represent more than $70 \%$ of the milk production in Brazil (Facó et al., 2002). Besides that, Brazil has a seasonal milk production due to differences in the availability of food and climate, with very different management and challenges faced in each season.

Therefore, we did the energy profile of crossbred Holstein x Gir dairy cows in a semi confinement system during two seasons for better understanding the metabolism of these animals during the transition period.

\section{MATERIAL AND METHODS}

This study was approved by the Ethics Committee on Animal Experimentation (CETEA/UFMG) under protocol number $82 / 2011$ and was done on a dairy farm in the municipality of Martinho Campos, Minas Gerais. The climate of the region is defined according to the Koppen classification as Aw, a tropical savanna climate with hot and rainy summers and dry and mild winters. The research consisted of two experimental periods, January to April 2011 (summer) and May to August 2011 (winter). The average temperatures were $25.5^{\circ} \mathrm{C}$ in the summer and $20.6^{\circ} \mathrm{C}$ in the winter. The maximum and minimum temperatures were respectively $36^{\circ} \mathrm{C}$ and $15.2^{\circ} \mathrm{C}$ in the summer and $34.3^{\circ} \mathrm{C}$ and $7.9^{\circ} \mathrm{C}$ in the winter. The total precipitation was $707.5 \mathrm{~mm}$ in the summer and $20.2 \mathrm{~mm}$ in the winter.

The herd was composed of 250 lactating cows, producing 5,000 liters of milk per day. In each experimental period 31 pluriparous crossbred Holstein x Gir dairy cows were used, varying $5 / 8$ to $31 / 32$ Holstein with lactation order from second to seventh and average daily production of $20 \mathrm{~L}$ of milk in the summer and $23 \mathrm{~L}$ in the winter.

The animals remained in mixed paddocks of Panicum maximum, Cynodon sp. and Brachiaria brizanta. Furthermore, they received concentrate and corn silage mixed in the trough. During winter, the diet was formulated only with fodder and corn silage. All diets were formulated to meet nutritional requirements according to NRC (2001). In all paddocks there were drinkers and troughs for mineral supplementation.

Blood was collected weekly by puncture of the coccygeal vein during the prepartum, beginning in the fourth week before the calving expected date, followed by a harvest within 24 hours after calving, and in the second, fifth, $10^{\text {th }}, 15^{\text {th }}, 21^{\text {th }}$ and $30^{\text {th }}$ days postpartum. Blood collection was always done before feeding the animals. Blood samples were centrifuged and serum or plasma were separated and frozen for later analysis.

Concentrations of triglycerides, cholesterol, glucose, gamma-glutamyl transferase (GGT), lactate dehydrogenase (LDH), aspartate aminotransferase (AST), non-esterified fatty acids (NEFA) and beta-hidroxibutirate (BHB) were measured using the technique of spectrophotometry in an automatic device with commercial kits.

The body condition score (BCS) of each animal was assessed at all times of blood collection using a scale of 1 (one) to five (5) points, with minimal variation of 0.5 point, according to Dirksen (1993).

The design was a split plot arrangement, in which the seasons consisted of plots and the times of blood collection were the subplots. The metabolic averages between times of blood collection were compared by the Scott-Knott test and between seasons using the SNK test. For BCS analysis the Dunn Multiple Comparison was used for comparison between periods of the year and the Mann-Whitney test for comparison between assessments (Sampaio, 2002).

Using the BHB analysis, subclinical ketosis were diagnosed using as a criteria the concentrations above $1.2 \mathrm{mmol} / \mathrm{L}$ according to LeBlanc (2010). The cutoffs NEFA above $0.4 \mathrm{mmol} / \mathrm{L}$ in prepartum and $0.7 \mathrm{mmol} / \mathrm{L}$ in the postpartum were used to assess the increased risk of disease according to LeBlanc et al. (2005) and Ospina et al. (2010). 


\section{RESULTS}

The days of blood collection influenced all metabolic analyzed, showing the adaptation of animals throughout the transition period.

The glucose concentrations were higher in the winter while the triglyceride and $\mathrm{LDH}$ concentrations were higher in the summer (Table 1 and 2). Along the transition period, the season influenced the concentrations of cholesterol, AST and GGT, showing a different pattern between summer and winter. However, the concentrations of cholesterol, NEFA and BHB were similar in the two seasons (Table 1).

Cholesterol concentrations, despite not having varied, showed a different pattern during each season. It had a decline from the prepartum until calving, more marked in the summer, and increased after 10 days postpartum in the summer and 5 days postpartum in the winter, reaching the highest levels on day 30 postpartum in the summer and 21 days postpartum in the winter (Table 1 and Figure 1). Distinctly, the serum triglyceride concentration declined until calving and remained at the same level throughout the postpartum period in both seasons (Table 1).

The plasma glucose concentration in both seasons was lower postpartum when compared to prepartum and, at calving, it rose to higher levels in the whole experimental period (Table 1 and Figure 1).

The NEFA concentrations rose from one week prepartum until calving as can be seen in Figure 1. On the day of calving, the concentrations of BHB were also increased. Both were stable up to five days postpartum and subsequently the concentrations of BHB remained high, while NEFA declined (Table 1 and Figure 1).

Table 1. Mean concentrations of cholesterol, triglycerides, glucose (mg/dL), NEFA, BHB (mmol/L) in crossbred cows in the fourth ( $-4 \mathrm{wk}$.), third (-3 wk.), second ( $-2 \mathrm{wk}$.) and first ( $-1 \mathrm{wk}$.$) weeks prepartum,$ on calving (Calv.) and in the second, fifth, $10^{\text {th }}, 15^{\text {th }}, 21^{\text {th }}$ and $30^{\text {th }}$ days postpartum in a semi-intensive system in summer and winter

\begin{tabular}{|c|c|c|c|c|c|c|c|c|c|c|c|c|c|}
\hline & \multirow{2}{*}{ SEASON } & \multicolumn{11}{|c|}{ TIME } & \multirow{2}{*}{ Mean } \\
\hline & & -4 wk & $-3 w k$ & -2 wk & $-1 \mathrm{wk}$ & Calv. & $2^{\circ} \mathrm{d}$ & $5^{\text {th }} \mathrm{d}$ & $10^{\text {th }} \mathrm{d}$ & $15^{\text {th }} \mathrm{d}$ & $21^{\text {th }} d$ & $30^{\text {th }} \mathrm{d}$ & \\
\hline \multirow{6}{*}{ 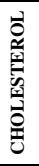 } & Summer & $76.5 \mathrm{aB}$ & $72.4 \mathrm{aB}$ & $63.6 \mathrm{aC}$ & $58.5 \mathrm{aC}$ & $50.8 \mathrm{aD}$ & $61.8 \mathrm{aC}$ & $55.1 \mathrm{aD}$ & $64.0 \mathrm{aC}$ & $72.4 \mathrm{aB}$ & $77.2 \mathrm{aB}$ & $88.8 \mathrm{aA}$ & 67.4 \\
\hline & $S D$ & 16.8 & 21.9 & 15.1 & 13.5 & 16.2 & 21.0 & 17.1 & 19.9 & 19.1 & 22.4 & 29.3 & 22.1 \\
\hline & Winter & $72.5 \mathrm{aD}$ & $67.0 \mathrm{aD}$ & $59.7 \mathrm{aE}$ & $51.2 \mathrm{aE}$ & $52.7 \mathrm{aE}$ & $53.4 \mathrm{aE}$ & 66.6aD & $84.4 \mathrm{aC}$ & $102.7 \mathrm{aB}$ & $115.9 \mathrm{aA}$ & $124.3 \mathrm{aA}$ & 77.3 \\
\hline & $S D$ & 20.5 & 20.1 & 18.1 & 15.1 & 27.1 & 13.1 & 13.1 & 17.5 & 30.4 & 29.1 & 30.8 & 33.3 \\
\hline & Average & 74.5 & 69.7 & 61.7 & 54.9 & 51.8 & 57.6 & 60.8 & 74.2 & 87.6 & 96.6 & 106.5 & 72.3 \\
\hline & $S D$ & 18.8 & 21.0 & 16.6 & 14.7 & 21.9 & 17.9 & 16.1 & 21.2 & 29.5 & 32.4 & 34.8 & 28.8 \\
\hline \multirow{6}{*}{ 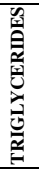 } & Summer & 43.9 & 41.2 & 42.1 & 35.0 & 28.7 & 26.5 & 29.6 & 27.2 & 32.2 & 26.0 & 25.2 & $32.50 \mathrm{a}$ \\
\hline & $S D$ & 12.4 & 8.7 & 9.1 & 10.8 & 13.9 & 13.4 & 13.5 & 14.0 & 14.6 & 14.0 & 13.6 & 14.1 \\
\hline & Winter & 37.3 & 33.0 & 31.8 & 29.1 & 18.0 & 20.6 & 20.2 & 23.8 & 23.5 & 21.3 & 22.4 & $25.55 \mathrm{~b}$ \\
\hline & $S D$ & 11.0 & 9.4 & 9.5 & 9.4 & 8.6 & 5.3 & 6.4 & 11.5 & 7.2 & 5.5 & 9.8 & 10.3 \\
\hline & Average & $40.6 \mathrm{~A}$ & $37.1 \mathrm{~A}$ & $37.0 \mathrm{~A}$ & $32.0 \mathrm{~B}$ & $23.3 \mathrm{C}$ & $23.5 \mathrm{C}$ & $24.9 \mathrm{C}$ & $25.5 \mathrm{C}$ & $27.9 \mathrm{C}$ & $23.7 \mathrm{C}$ & $23.8 \mathrm{C}$ & 29.0 \\
\hline & $S D$ & 11.9 & 9.9 & 10.6 & 10.4 & 12.8 & 10.5 & 11.5 & 12.8 & 12.2 & 10.7 & 11.8 & 12.7 \\
\hline \multirow{6}{*}{ 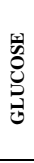 } & Summer & 45.4 & $44.9 \mathrm{bB}$ & $42.7 \mathrm{bB}$ & $44.3 \mathrm{bB}$ & $50.7 \mathrm{bA}$ & $41.5 \mathrm{bC}$ & $38.7 \mathrm{bD}$ & $34.6 \mathrm{bE}$ & $37.6 \mathrm{bD}$ & $38.8 \mathrm{bD}$ & $40.9 \mathrm{bC}$ & 41.8 \\
\hline & $S D$ & 4.7 & 4.8 & 3.3 & 4.2 & 16.4 & 7.3 & 8.2 & 7.1 & 7.3 & 7.4 & 7.3 & 8.8 \\
\hline & Winter & 51.1 & $50.3 \mathrm{aC}$ & $52.1 \mathrm{aB}$ & $52.8 \mathrm{aB}$ & $62.6 \mathrm{aA}$ & $49.2 \mathrm{aD}$ & $51.0 \mathrm{aD}$ & $49.8 \mathrm{aD}$ & $48.1 \mathrm{aD}$ & $50.5 \mathrm{aD}$ & $51.4 \mathrm{aD}$ & 51.7 \\
\hline & $S D$ & 5.5 & 5.7 & 5.0 & 3.9 & 28.5 & 8.1 & 6.1 & 9.1 & 6.6 & 7.6 & 7.7 & 11.0 \\
\hline & Average & 48.2 & 47.6 & 47.4 & 48.6 & 56.7 & 45.4 & 44.9 & 42.2 & 42.9 & 44.6 & 46.1 & 46.8 \\
\hline & $S D$ & 5.9 & 5.9 & 6.3 & 5.9 & 23.7 & 8.6 & 9.4 & 11.2 & 8.7 & 9.5 & 9.1 & 11.2 \\
\hline \multirow{6}{*}{$\underset{D}{D}$} & Summer & 0.3 & 0.3 & 0.3 & 0.4 & 0.6 & 0.8 & 0.9 & 0.8 & 0.7 & 0.6 & 0.7 & $0.577 \mathrm{a}$ \\
\hline & $S D$ & 0.1 & 0.1 & 0.2 & 0.2 & 0.5 & 1.2 & 1.3 & 0.9 & 0.7 & 0.5 & 0.6 & 0.7 \\
\hline & Winter & 0.5 & 0.5 & 0.5 & 0.5 & 0.6 & 0.7 & 0.8 & 0.6 & 0.5 & 0.6 & 0.6 & $0.581 \mathrm{a}$ \\
\hline & $S D$ & 0.2 & 0.2 & 0.2 & 0.2 & 0.5 & 0.4 & 0.8 & 0.4 & 0.2 & 0.3 & 0.2 & 0.4 \\
\hline & Average & $0.39 \mathrm{~B}$ & $0.39 \mathrm{~B}$ & $0.38 \mathrm{~B}$ & $0.48 \mathrm{~B}$ & $0.60 \mathrm{~A}$ & $0.72 \mathrm{~A}$ & $0.84 \mathrm{~A}$ & $0.69 \mathrm{~A}$ & $0.59 \mathrm{~A}$ & $0.61 \mathrm{~A}$ & $0.65 \mathrm{~A}$ & 0.6 \\
\hline & $S D$ & 0.2 & 0.2 & 0.2 & 0.2 & 0.5 & 0.9 & 1.0 & 0.7 & 0.5 & 0.4 & 0.5 & 0.6 \\
\hline \multirow{6}{*}{ 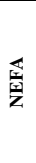 } & Summer & 0.0 & 0.1 & 0.1 & 0.3 & 0.3 & 0.3 & 0.4 & 0.2 & 0.2 & 0.2 & 0.1 & $0.21 \mathrm{a}$ \\
\hline & $S D$ & 0.4 & 0.2 & 0.3 & 0.2 & 0.2 & 0.3 & 0.3 & 0.2 & 0.2 & 0.2 & 0.1 & 0.2 \\
\hline & Winter & 0.2 & 0.1 & 0.2 & 0.2 & 0.3 & 0.2 & 0.3 & 0.3 & 0.2 & 0.2 & 0.2 & $0.21 \mathrm{a}$ \\
\hline & $S D$ & 0.2 & 0.2 & 0.2 & 0.2 & 0.3 & 0.2 & 0.2 & 0.2 & 0.1 & 0.1 & 0.2 & 0.2 \\
\hline & Average & 0.1 & $0.12 \mathrm{D}$ & $0.16 \mathrm{D}$ & $0.22 \mathrm{~B}$ & $0.29 \mathrm{~A}$ & $0.28 \mathrm{~A}$ & $0.32 \mathrm{~A}$ & $0.24 \mathrm{~B}$ & $0.19 \mathrm{C}$ & $0.20 \mathrm{C}$ & $0.15 \mathrm{C}$ & 0.2 \\
\hline & $S D$ & 0.2 & 0.2 & 0.3 & 0.2 & 0.2 & 0.2 & 0.3 & 0.2 & 0.2 & 0.2 & 0.2 & 0.2 \\
\hline
\end{tabular}

Means followed by different capital letters in lines differ by the Scott-Knott test $(\mathrm{P}<0.05)$. Means followed by different lowercase letters in columns differ by the SNK test $(\mathrm{P}<0.05)$. SD $=$ Standard deviation. 

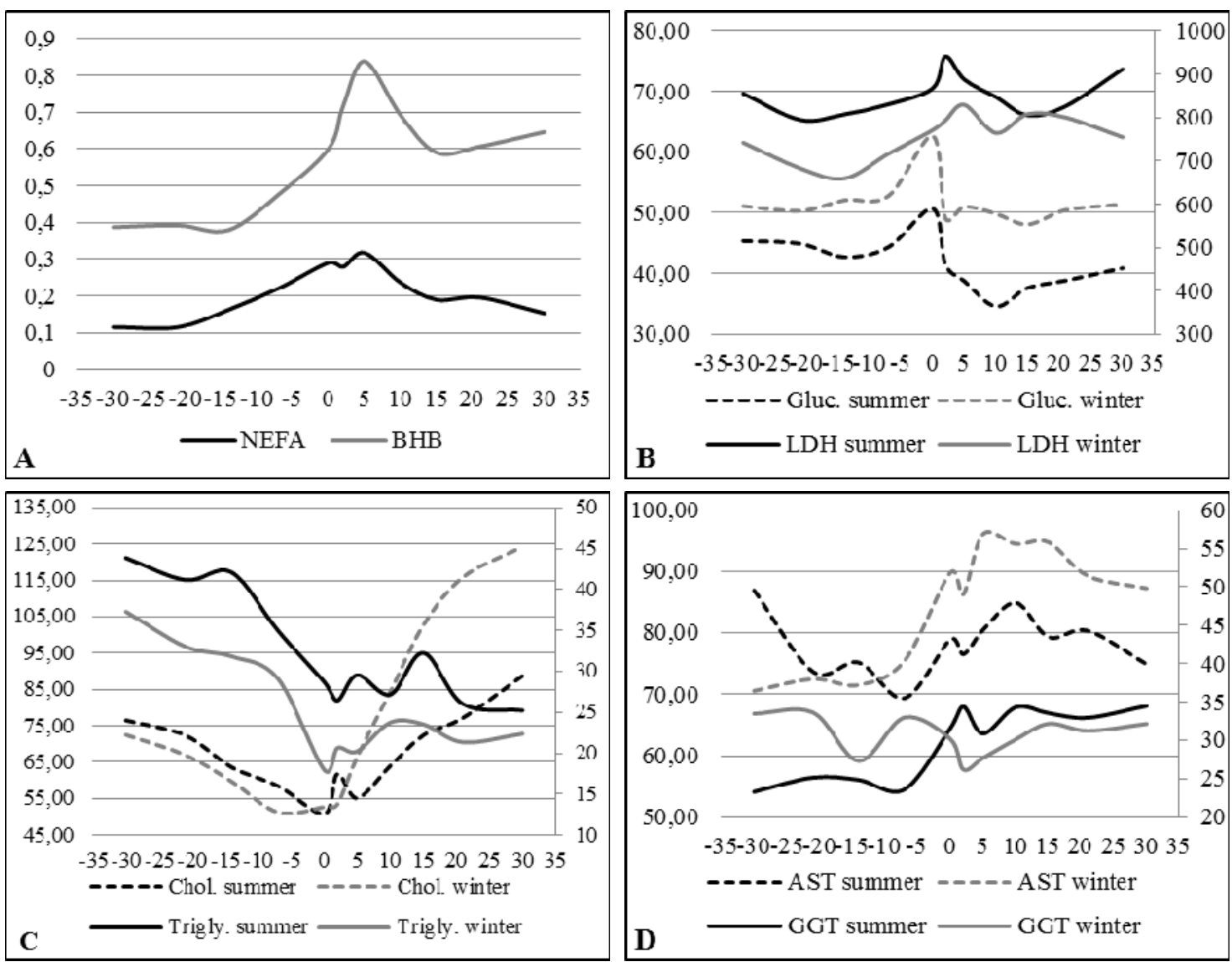

Figure 1. Effect of season during the transition period on NEFA and BHB (mmol/L) in Figure A, glucose (left axis; $\mathrm{mg} / \mathrm{dL}$ ) and LDH (right axis; U/L) in Figure B, triglycerides (left axis; mg/dL) and cholesterol (right axis; mg/dL) in Figure C, AST (left axis; U/L) and GGT (right axis; U/L) in Figure D.

The overall frequency of animals with NEFA values above $0.4 \mathrm{mmol} / \mathrm{L}$ in prepartum was $32.26 \%$ in the summer and $29.03 \%$ in the winter. At calving and during the postpartum, no animal showed NEFA concentration above $0.7 \mathrm{mmol} / \mathrm{L}$ (Figure 1).

Regarding the concentrations of BHB postpartum, $22.58 \%$ of the animals in summer and $19.35 \%$ in the winter had subclinical ketosis at some point. The maximum frequency of subclinical ketosis occurred on the fifth day postpartum, when $13.33 \%$ and $9.68 \%$ of cows had occurrences in the summer and winter, respectively.

The GGT activity in the summer and activities of LDH and AST increased postpartum (Table 2 and Figure 1). In the winter, the GGT activity varied more. Despite variation, the serum activity of GGT, AST and LDH always remained within the reference values for the species (Kaneko et al., 2008; Smith, 2009). 


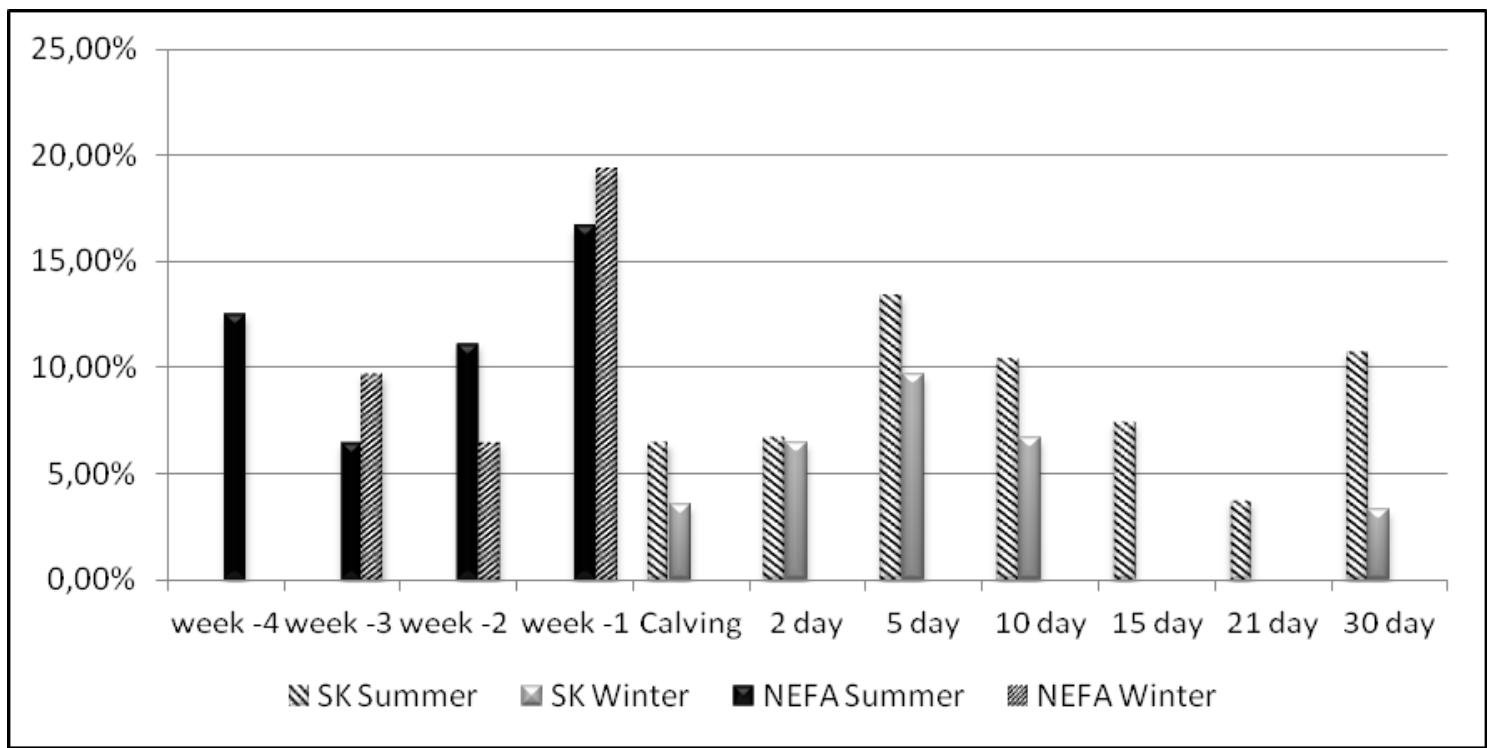

Figure 1: Incidence of subclinical ketosis (SK) and cows with serum concentrations of NEFA above $0.4 \mathrm{mmol} / \mathrm{L}$ in prepartum and $0.7 \mathrm{mmol} / \mathrm{L}$ in postpartum in a semi-intensive system in summer and winter.

Table 2. Average activity of GGT, AST and LDH (U / L) in pluriparous crossbred cows in the fourth ( -4 wk.), third ( -3 wk.), second (-2 wk.) and first (-1 wk.) weeks prepartum, on calving (Calv.) and in the second, fifth, $10^{\text {th }}, 15^{\text {th }}, 21^{\text {th }}$ and $30^{\text {th }}$ days postpartum in a semi-intensive system in summer and winter

\begin{tabular}{|c|c|c|c|c|c|c|c|c|c|c|c|c|c|}
\hline & \multirow[b]{2}{*}{ SEASON } & \multicolumn{11}{|c|}{ TIME } & \multirow[t]{2}{*}{ Mean } \\
\hline & & $-4 \mathrm{wk}$ & $-3 \mathrm{wk}$ & $-2 w k$ & $-1 \mathrm{wk}$ & Calv. & $2^{\circ} \mathrm{d}$ & $5^{\text {th }} d$ & $10^{\text {th }} \mathrm{d}$ & $15^{\text {th }} \mathrm{d}$ & $21^{\text {th }} d$ & $30^{\text {th }} \mathrm{d}$ & \\
\hline \multirow{6}{*}{$\begin{array}{l}\qquad \\
0 \\
0\end{array}$} & Summer & $23.3 \mathrm{bB}$ & $25.2 \mathrm{bB}$ & $24.9 \mathrm{aB}$ & $23.7 \mathrm{bB}$ & $31.6 \mathrm{aA}$ & $34.4 \mathrm{aA}$ & $30.9 \mathrm{aA}$ & $34.4 \mathrm{aA}$ & $33.6 \mathrm{aA}$ & $33.0 \mathrm{aA}$ & $34.5 \mathrm{aA}$ & 29.9 \\
\hline & $S D$ & 9.9 & 11.4 & 8.4 & 9.7 & 12.6 & 13.5 & 7.5 & 9.2 & 9.0 & 7.4 & 8.6 & 10.8 \\
\hline & Winter & $33.5 \mathrm{aA}$ & $33.7 \mathrm{aA}$ & $27.4 \mathrm{aB}$ & $33.0 \mathrm{aA}$ & $30.2 \mathrm{aA}$ & $26.2 \mathrm{bB}$ & $27.7 \mathrm{aB}$ & $30.1 \mathrm{aA}$ & $32.2 \mathrm{aA}$ & $31.3 \mathrm{aA}$ & $32.2 \mathrm{aA}$ & 30.7 \\
\hline & $S D$ & 19.6 & 16.4 & 11.1 & 11.8 & 13.3 & 12.4 & 12.9 & 10.4 & 12.2 & 12.9 & 13.3 & 13.4 \\
\hline & Average & 28.4 & 29.4 & 26.1 & 28.4 & 30.9 & 30.4 & 29.3 & 32.3 & 32.9 & 32.1 & 33.4 & 30.3 \\
\hline & $S D$ & 16.6 & 14.7 & 9.9 & 11.7 & 12.9 & 13.5 & 10.7 & 10.0 & 10.6 & 10.5 & 11.3 & 12.2 \\
\hline \multirow{6}{*}{$\overrightarrow{4}$} & Summer & $86.9 \mathrm{aA}$ & $73.7 \mathrm{aB}$ & $75.2 \mathrm{aB}$ & $69.4 \mathrm{aB}$ & $79.0 \mathrm{aA}$ & $76.5 \mathrm{aB}$ & $80.5 \mathrm{aA}$ & $84.9 \mathrm{aA}$ & $79.3 \mathrm{aA}$ & $80.4 \mathrm{aA}$ & $74.9 \mathrm{aB}$ & 78.3 \\
\hline & $S D$ & 21.9 & 17.1 & 23.8 & 16.6 & 12.4 & 13.6 & 18.4 & 24.7 & 13.5 & 15.7 & 12.4 & 17.8 \\
\hline & Winter & $70.6 \mathrm{aB}$ & $72.5 \mathrm{aB}$ & 71.6aB & $75.5 \mathrm{aB}$ & $89.8 \mathrm{aA}$ & $86.3 \mathrm{aA}$ & $96.2 \mathrm{aA}$ & $94.5 \mathrm{aA}$ & $94.8 \mathrm{aA}$ & $89.3 \mathrm{aA}$ & $87.3 \mathrm{aA}$ & 84.3 \\
\hline & $S D$ & 11.8 & 14.1 & 11.0 & 15.8 & 15.7 & 14.9 & 22.0 & 24.3 & 20.7 & 20.1 & 19.0 & 19.9 \\
\hline & Average & 78.8 & 73.1 & 73.4 & 72.5 & 84.4 & 81.4 & 88.3 & 89.7 & 87.1 & 84.8 & 81.1 & 81.3 \\
\hline & $S D$ & 18.4 & 15.5 & 18.3 & 16.0 & 14.9 & 14.6 & 21.6 & 24.7 & 19.1 & 18.5 & 17.2 & 19.1 \\
\hline \multirow{6}{*}{$\begin{array}{l}\vec{I} \\
\vec{a} \\
\vec{u}\end{array}$} & Summer & 855.4 & 795.0 & 807.4 & 830.7 & 867.9 & 941.0 & 887.7 & 847.4 & 805.2 & 826.2 & 912.0 & $852.3 a$ \\
\hline & $S D$ & 266.1 & 225.5 & 268.6 & 239.4 & 196.8 & 339.1 & 256.7 & 238.4 & 152.9 & 225.7 & 255.5 & 246.2 \\
\hline & Winter & 742.2 & 683.0 & 659.4 & 716.6 & 771.3 & 793.9 & 829.3 & 764.3 & 808.0 & 800.3 & 754.9 & $756.6 \mathrm{~b}$ \\
\hline & $S D$ & 144.6 & 140.3 & 115.2 & 152.5 & 155.3 & 161.5 & 175.6 & 195.0 & 187.2 & 165.4 & 116.6 & 163.5 \\
\hline & Average & 798.7B & 738.9B & 733.4B & 773.6B & $819.6 \mathrm{~A}$ & $867.4 \mathrm{~A}$ & $858.5 \mathrm{~A}$ & $805.8 \mathrm{~A}$ & $806.6 \mathrm{~A}$ & $813.2 \mathrm{~A}$ & $833.4 \mathrm{~A}$ & 804.5 \\
\hline & $S D$ & 215.0 & 195.9 & 222.6 & 207.2 & 183.4 & 272.3 & 219.4 & 221.0 & 169.7 & 195.4 & 210.0 & 214.0 \\
\hline
\end{tabular}

Means followed by different capital letters in lines differ by the Scott-Knott test $(\mathrm{P}<0.05)$. Means followed by different lowercase letters in columns differ by the SNK test $(\mathrm{P}<0.05)$. SD $=$ Standard deviation.

The cows that calved during winter had a greater BCS than cows that calved during summer $(3.7$ versus 3.4), but they lost more BCS until calving, when the BCS was similar between the two seasons. The mean of BCS lost was 0.7 for cows during the winter and 0.4 for cows in the summer (Table 3). 
Table 3. Values of body condition score (BCS) of pluriparous crossbred cows in the fourth (-4 wk.), third $(-3$ wk.), second ( -2 wk.) and first ( -1 wk.) weeks prepartum, on calving (Calv.) and in the second, fifth, $10^{\text {th }}, 15^{\text {th }}, 21^{\text {th }}$ and $30^{\text {th }}$ days postpartum in semi-intensive system in summer and winter

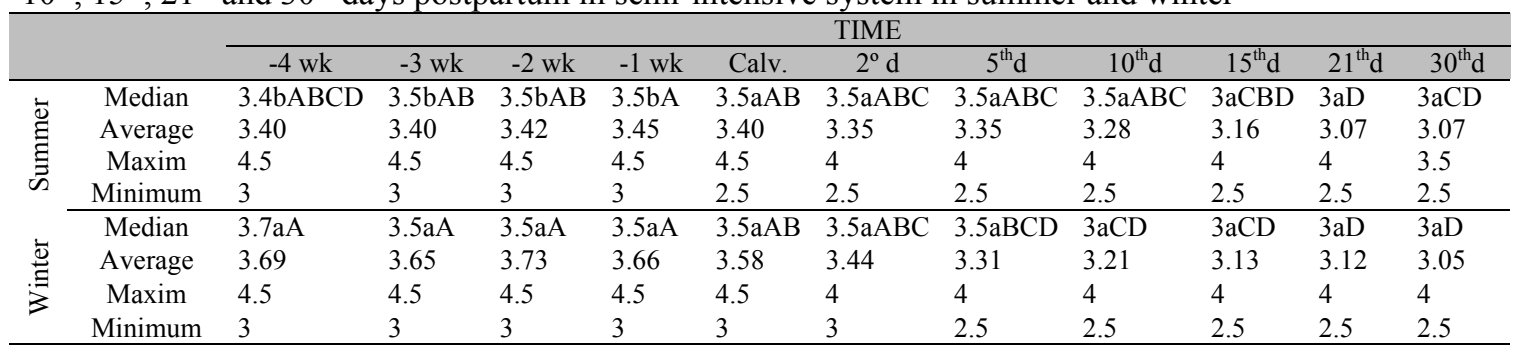

Means followed by different capital letters in lines differ by the Dunn's Multiple Comparison test $(\mathrm{P}<0.05)$. Means followed by different lowercase letters in columns differ by the Mann-Whitney test $(\mathrm{P}<0.05)$.

\section{DISCUSSION}

The rise in cholesterol levels after calving reflects an increase in the uptake of lipids in the liver, suggesting that the increase in cholesterol levels is associated with higher tissue mobilization, increase of food intake, greater synthesis of steroid hormones and lipoproteins, which are physiological processes of the postpartum (Stengärde, 2010; Kaneko et al., 2008). The patters showed by cholesterol concentrations are very similar and related to food intake. Due to this relation, in the summer the variation of food intake was probably higher. A similar pattern was demonstrated by Godoy et al. (2004) in zebu and crossbreed cows.

The fall in triglycerides levels during postpartum occurs because of the use of triglycerides by mammary glands as precursors of milk fat (Bauman and Griinari, 2003). Aside from the mammary gland, the liver begins to remove more triglycerides from the bloodstream in lactating cows (Reynolds et al., 2003).

The rise of glucose on calving day occurs very quickly, falling after few hours postpartum (Aquino Neto, 2012). This rise is a physiological process, a result of increased concentration of glucagon, catecholamines and glucocorticoids, mechanisms to prioritize the use of glucose by the mammary gland (Park et al., 2010).

The results for plasma concentration of NEFA demonstrated that the mobilization of adipose tissue has intensified in the first week prepartum and remained higher until the fifth day postpartum as described also by Reynolds et al. (2003), LeBlanc (2005), Park et al. (2010) and Paula et al. (2011).
Increasing concentrations of BHB on calving day and postpartum occurred one week after the increase in NEFA, as this is the major cause of ketogenesis. This also demonstrates that the amount of NEFA that reached the liver was greater than the capacity of this organ to oxidize them completely (Ospina et al., 2010).

The results show a situation in which although there were lower levels of glucose circulating in the summer there was no greater tissue mobilization demonstrated by the similarity of NEFA and BHB in the two seasons. By observing the BCS of animals, we can perceive an indication of the opposite (Table 3). Cows that calved in the winter began with higher BCS but lost more BCS until calving.

One factor that may explain these findings is heat stress. Heat stressed cows have increased insulin response, making them metabolically inflexible, decreasing the oxidation of NEFA and the use of ketone bodies as an energy source. Thus, cows under heat stress, even in negative energy balance, do not increase circulating concentrations of NEFA and BHB and have lower levels of glucose than cows on classical negative energy balance. This mechanism is a form of the cow producing less heat, since the oxidation of glucose releases a smaller amount of energy as heat oxidation NEFA (13\% difference) (Wheelock, 2010; Baumgard and Rhoads, 2013).

The thermo neutral zone for dairy cattle is between $5^{\circ} \mathrm{C}$ and $25^{\circ} \mathrm{C}$ and can vary depending on humidity (Ferreira et al., 2009). Maximum temperatures during the two periods reached higher values than those considered ideal for dairy cattle, but the average and minimum temperatures and the precipitation are largely 
different between the two periods. With these variations, we observed that the animals were more likely to suffer from heat stress in the summer.

The frequency of animals with NEFA concentrations above $0.4 \mathrm{mmol} / \mathrm{L}$ in the first week prepartum was $19.35 \%$ in the summer and $16.67 \%$ in the winter. These numbers are higher than the $10 \%$ suggested as optimum by Oetzel (2004). Animals that have concentrations of NEFA above $0.4 \mathrm{mmol} / \mathrm{L}$ in prepartum are two to four times more likely to develop displaced abomasum, 1.8 times more likely to develop ketosis and retained placenta, 2.2 times more likely to have metritis and two times more likely to be discarded in the first 60 days in milk (LeBlanc, 2006; Ospina et al., 2010).

The larger number of animals with subclinical ketosis $(22.58 \%$ in the summer and $19.35 \%$ in the winter) is a warning, since these animals have 4 to 8 times more chance to have displaced abomasum, are less likely to become pregnant in the first service, produce less milk, have increased duration and severity of mastitis, are 2.3 times more likely to develop metritis and 4.9 times more likely to develop clinical ketosis (LeBlanc, 2006, Ospina et al., 2010).

Regarding the increased activity of liver enzymes in the postpartum, the increase of the blood flow to the liver and the enhanced hepatic metabolism after calving may be the cause. In these circumstances there is a cellular adaptation (Reynolds et al., 2003; Thall, 2012). Moreover, the large hepatic blood flow in postpartum may cause mild hypoxia, resulting in damage to hepatocytes. In these cases, often the values found were within normal (Thrall, 2012).

Particularly, the increasing concentration of LDH in the postpartum is a sign of the use of lactate for glucose formation near calving due to lack of other sources for gluconeogenesis, making the Cori cycle essential for this period (Reynolds et al., 2003). Especially in the summer, when the activity of LDH was higher and serum glucose was lower, lactate may have played an important role to supply the energy needs.

The increased AST activity is related to the occurrence of catabolism of muscle tissue to use proteins for gluconeogenesis (Herdt, 2000).
Similarly, Aquino Neto (2012) reported increased enzymatic activity of AST in the early postpartum due to muscular effort during calving, causing damage to muscle tissue and release of this enzyme (Fagliari et al., 1998).

Despite the strong influence of seasons on the metabolic profile of animals, it is difficult to isolate the effect of different factors existing in summer and winter, such as temperature, rainfall and diet.

\section{CONCLUSION}

The metabolic profile of crossbred Holstein x Gir cows in a semi-confined system differ greatly between summer and winter, indicating that each season presents its own challenges, such as the heat stress that cows undergo during summer with decreased concentrations of glucose without incising NEFA and BHB levels. In both seasons cows went through great changes in metabolic profile, with increased hepatic metabolism in postpartum, with more cholesterol production increasing the use of triglycerides and lipolysis. With all these changes, some animals could not maintain a healthy metabolism and went through subclinical ketosis or had high NEFA, making them more susceptible to other diseases.

\section{REFERENCES}

AQUINO NETO, H.M. Perfil hidroeletrolítico, ácido-base, metabólico e mineral de vacas leiteiras no pós-parto imediato e avaliação da fluidoterapia oral. 2012. 121f. Tese (Doutorado em Ciência Animal) - Escola de Veterinária, Universidade Federal de Minas Gerais, Belo Horizonte, MG.

BAUMAN, D.E.; GRIINARI, J.M. Nutritional regulation of milk fat synthesis. Annu. Rev. Nutr., v.23, p.203-227, 2003.

BAUMGARD, L.H.; RHOADS, R.P. Effects of heat stress on postabsortive metabolism and energetics. Annu Rev Anim Biosci., v.1, p.311337, 2013.

DIRKSEN, G.; GRÜNDER, H. D.; STÖBER, M. Rosenberger: Exame Clínico dos Bovinos. 3. ed. Rio de Janeiro: Guanabara Koogan S.A, 1993. 419p. 
FACÓ, O.; LÔBO, R.N.B.; MARTINS FILHO, R. et al. Análise do desempenho produtivo de diversos grupos genéticos Holandês-Gir no Brasil. Rev. Bras. Zootec., v.31, p. 1944-1952, 2002.

FAGLIARI, J.J.; SANTAN, A.E.; MARCHIO, W. et al. Constituintes sanguíneos de vacas das raças Nelore (Bos indicus) e Holandesa (Bostaurus) e de bubalinos (Bubalus bubalis) da raça Murah durante a gestação, no dia do parto e no puerpério. Arq. Bras. Med. Vet. Zootec., v.50, p. 273-282, 1998.

FERREIRA, F.; CAMPOS, W.E.; CARVALHO, A.U. et al. Parâmetros clínicos, hematológicos, bioquímicos e hormonais de bovinos submetidos ao estresse calórico. Arq. Bras. Med. Vet. Zootec., v.61, p. 769-776, 2009.

GODOY M.M.; ALVES, J.B.; MONTEIRO, A.L.G. et al. Parâmetros Reprodutivo e Metabólico de Vacas da Raça Guzerá Suplementadas no Pré e Pós-Parto. Rev. Bras. Zootec., v.33, p.103-111, 2004.

HERDT, T.H. Ruminant adaptation to negative energy balance: Influences on the etiology of ketosis and fatty liver. Vet. Clin. North Am. Food Anim. Pract., v.16, p.215-230, 2000.

KANEKO, J.J.; HARVEY, J.W.; BRUSS, M.L. Clinical biochemistry of domestic animal. 6. ed. Oxford: Elsevier, 2008. 918p.

LEBLANC, S.J. Health in the transition period and reproductive performance. WCDS Adv. Dairy Technol., v.22, p.97-110, 2010.

LEBLANC, S.J. Monitoring programs for transition dairy cows. In: WORLD BUIATRICS CONGRESS, 24., 2006, Nice. Proceedings... Nice: World Association for Buiatrics, 2006. p.460-472.

LEBLANC, S.J.; LESLIE，K.E.; DUFFIELD, T.F. Metabolic predictors of displaced abomasum in dairy cattle. J. Dairy Sci., v.88, p. 59-170, 2005.

MULLIGAN, F. J.; O'GRADY, L.; RICE, D. A.; et al. A herd health approach to dairy cow nutrition and production diseases of the transition cow. Anim. Rep. Sci., v.96, p. 331-353, 2006.
NATIONAL RESEARCH COUNCIL, Nutritional requirements of dairy cattle.7.ed. Washington: Academy Press, 2001, 408p.

OETZEL, G.R. Monitoring and testing dairy herds for metabolic disease. Vet. Clin. North Am. Food Anim. Pract., v.20, p.651-674, 2004.

OSPINA, P.A.; NYDAM D.V.; STOKOL T. et $a l$. Evaluation of nonesterified fatty acids and $\beta$ hydroxybutyrate in transition dairy cattle in the northeast United States: Critical thresholds for prediction of clinical diseases. J. Dairy Sci., v.93, p.546-554, 2010.

PARK, A.F.; SHIRLEY, J.E.; TITGEMEYER, E.C. et al. Characterization of plasma metabolites in holstein dairy cows during periparturient period. J. Dairy Sci., v.5, p.253263, 2010.

PAULA, V.M.; FREITAS M.D.; MOREIRA T.F. et al. Perfil mineral e bioquímico de vacas leiteiras no período de transição em um sistema semi-intensivo em Minas Gerais. Vet. Zootec., v.18, suppl. 3, p. 650-654, 2011.

REYNOLDS, C.K.; AIKMAN, P.C.; LUPOLI, B. et al. Splanchnic metabolism of dairy cows during the transition from late gestation through early lactation. J. Dairy Sci., v.86, p.1201-1217, 2003.

SAMPAIO, I.B.M. Estatística aplicada a experimentação animal. 2.ed. Belo Horizonte: FEPMVZ, 2002, 265p.

SMITH, B.P. Large animal internal medicine. 4. ed. St Louis: Mosby-Elsevie, 2009. 1821p.

STENGÄRDE, L. Displaced abomasum and ketosis in dairy cows blood profiles and risk factors. 2010. 76f. Thesis (Doctorate in Veterinary Medicine) - Swedish University of Agricultural Sciences, Uppsala.

THRALL, M.A.; WEISER, G..; ALLISON, R.W. et al. Veterinary hematology and clinical chemistry. 2. ed. Ames: Wiley-Blackwell, 2012. 776p.

WHEELOCK, J.B.; RHOADS, R.P.; VANBAALE, M.J., et al. Effects of heat stress on energetic metabolism in lactating Holstein cows. J. Dairy Sci., v.93, p.644-655, 2010. 